\title{
Implementasi SMED: Perbaikan Waktu Changeover Part pada Line Produksi Seat di PT. Selamat Sempurna, Tbk
}

\section{SMED Implementation: Changeover Part Time Improvement at Seat Line Production PT. Selamat Sempurna, Tbk}

\author{
Puji Rahayu' ${ }^{1}$, Joko Supono ${ }^{2}$, Nur Anisa ${ }^{3}$ \\ 1,2. Program Studi Teknik Industri, Fakultas Teknik, Universitas Muhammadiyah Tangerang \\ 1puji.umt16@gmail.com , 2ijoko.supono@yahoo.co.id, ${ }^{3}$ nur.anisa9304@gmail.com
}

\begin{abstract}
PT. Selamat Sempurna, Tbk is a company that manufactures automotive parts, namely car filters. This filter product has many part numbers. In this company has one of the production lines, namely Line Seat Press Shop, this line produces components from filters, namely seat components. Seat is the main part of the filter component that functions as a filter holder to the engine. This Seat component consists of several part numbers (shapes or variations) following the filter product, and some part numbers handled by the manual engine B070 \& L224 will affect the changes in the production engine settings. This production machine includes machines that require time in a slow setup process for switching dies when switching from one part number to another part number compared to other machines, because the element of the process setting is long. With a fishbone diagram, the root cause of the Change Over Part long problem on the machine is from the method category (there is no preparation desk dies and there is not separation of external setup and internal setup). Previously the time needed for Change Over Part was 1961 seconds. After knowing the root cause of the problem and the improvement of the time needed is only 866 seconds. The time difference is 1067 seconds, so save on average time 1095 seconds or 18 minutes / setup.
\end{abstract}

Keywords: Filter product, Change Over part (COP), Fishbone Diagram, Setup, Process Elements.

\begin{abstract}
ABSTRAK
PT. Selamat Sempurna, Tbk adalah perusahaan yang memproduksi automotif part yaitu filter mobil. Produk filter ini mempunyai banyak part number (variasi/ bentuk). Di dalam perusahaan ini memiliki salah satu line produksi yaitu Line Seat Press Shop, Line ini memproduksi komponen dari filter yaitu komponen seat. Seat adalah bagian utama dari komponen filter yang berfungsi sebagai dudukan filter ke mesin. Komponen Seat ini terdiri dari beberapa part number (bentuk atau variasi) mengikuti produk filter tersebut, dan beberapa part number yang di tangani oleh mesin manual B070 \& L224 akan berimbas pada perubahan setting mesin produksi tersebut. Mesin produksi ini termasuk mesin yang membutuhkan waktu dalam proses setup yang lambat untuk pergantian dies (cetakan) saat peralihan dari part number yang satu ke part number yang lainnya dibandingkan dengan mesin lainnya, karena elemen proses setting panjang. Dengan diagram fishbone, akar penyebab masalah Change Over Part panjang di mesin tersebut adalah dari kategori methode (belum adanya meja persiapan dies dan tidak ada pemisahan setup eksternal dan setup internal). Sebelumnya waktu yang dibutuhkan untuk COP adalah 1961 detik. Sesudah di ketahui akar penyebab masalah dan improvement waktu yang dibutuhkan hanya 866 detik. Selisih waktunya 1067 detik, jadi hemat waktu rata - rata : 1095 detik atau 18 menit/ setup.
\end{abstract}

Kata Kunci: Filter product, Change Over part (COP), Fishbone Diagram, Setup, Process Elements. 


\section{PENDAHULUAN}

\subsection{Latar Belakang}

PT. Selamat Sempurna (PT. SS), Tbk adalah perusahaan otomotif yang memproduksi automotif part yaitu produk filter mobil. Produk filter ini mempunyai banyak part number (variasi/ bentuk). Di dalam perusahaan ini memiliki salah satu line produksi yaitu Line Seat Press Shop, Line ini memproduksi komponen dari filter yaitu komponen Seat. Komponen Seat adalah bagian utama dari komponen produk filter yang berfungsi sebagai dudukan filter ke mesin. Komponen seat ini juga mempunyai banyak part number (bentuk atau variasi) mengikuti produk filter tersebut, dan beberapa part number komponen seat yang di tangani oleh mesin manual B070 \& L224 akan berimbas pada perubahan setting mesin produksi tersebut. Mesin produksi ini termasuk mesin yang membutuhkan waktu dalam proses setup yang lama untuk pergantian dies (cetakan) saat peralihan dari part number yang satu ke part number yang lainnya dibandingkan dengan mesin lainnya, karena elemen proses setting panjang. Waktu Change Over Part (COP) tiap mesin bisa di lihat di Tabel 1.1

\begin{tabular}{lccc}
\multicolumn{3}{c}{ Tabel 1. Waktu Change Over Part Mesin B070 \& L224 } \\
\cline { 2 - 4 } No. & Mesin & Waktu COP \\
\hline 1. & B070 1 & Proses 2 & (Detik) \\
2. & B075 & L224 & 1961 \\
3. & L226 & B069 & 1360 \\
4. & B072 & L225 & 1270 \\
5. & B071 & B008 & 1230 \\
\end{tabular}

Sumber: Dept. Produksi PT. SS, 2019

Waktu changeover merupakan suatu waste yang perlu dihilangkan atau diminimalkan. Waktu changeover part pada tiap proses yang tinggi berdampak pada nilai uptime yang kecil dan bergesernya jadwal produksi sehingga tidak dapat memenuhi permintaan konsumen tepat waktu. Dengan banyaknya part number komponen seat yang di produksi di mesin manual B070 \& L224, akan berimbas pada perubahan setting mesin produksi tersebut. Mesin produksi ini termasuk mesin yang membutuhkan waktu dalam proses setup yang lama untuk pergantian dies (cetakan) saat peralihan dari part number yang satu ke part number yang lainnya dibandingkan dengan mesin lainnya, karena elemen proses setting panjang. Untuk mengeliminasi waste pada mesin produksi B070 dan L224 maka PT. SS perlu melakukan perbaikan waktu changeover.

\section{LANDASAN TEORI}

\section{Changeover dan SMED}

Menurut Goubergen \& Sherali (2004) dalam jurnal Syafiq (2018), changeover adalah seluruh aktifitas dan waktu yang diperlukan antara produksi produk terakhir sampai mulai produksi produk berikutnya dalam proses pergantian jenis produk. Seluruh aktifitas changeover tersebut dianggap sebagai waste karena apa yang dilakukannya tidak memberikan nilai tambah terhadap produk akhir dan menyebabkan kenaikan biaya produksi, oleh karenanya harus dihilangkan atau paling tidak diturunkan seminimal mungkin. Ada dua pendapat untuk menurunkan waktu changeover yaitu menurunkan frekuensi changeover dan menurunkan waktu yang diperlukan untuk changeover. Sebagian besar inisiatif menanggulagi waktu changeover adalah dengan pendekatan single 
minute exchange dies (SMED) yang diperkenalkan oleh Shigeo Shingo. SMED dulu diusulkan sebagai alat perbaikan bengkel yang berfokus pada perbaikan berbiaya rendah dan berbasis perbaikan kaizen, serta membutuhkan langsung keterlibatan personel tim produksi, yang pada akhirnya berevolusi menjadi sebuah bagian dari Toyota production system yang banyak digunakan secara global pada berbagai industri. SMED diklaim sebagai sebuah pendekatan ilmiah untuk mengatur pengurangan waktu yang dapat diterapkan di pabrik dan mesin apa pun (Feraddas \& Salonitis, 2013).

Metode SMED mengkategorisasi kegiatannya kedalam dua pengaturan setup, yaitu setup internal dan setup eksternal. Setup internal adalah kegiatan yang dilakukan pada saat mesin dalam keadaan mati, dan setup eksternal adalah jenis kegiatan yang dilakukan pada saat mesin sedang beroperasi. Baik setup internal dan eksternal melibatkan jenis operasi yang berbeda, seperti persiapan, penyesuaian sete;ah proses, pemeriksaan bahan, pemasangan dan pelepasan alat, pengaturan dan kalibrasi, pengukuran, uji coba, penyesuaian dan sebagainya (Shingo, 1985). Gambar 1. memberikan ilustrasi aktifitas yang tergolong kedalam kegiatan setup.

Tahapan pada metode SMED menurut Shingo (1985) terbagi kedalam tiga tahapan utama, yaitu (1) memisahkan pengaturan setup internal dan setup eksternal, (2) mengidentifikasi aktifitas apa saja yang termasuk kategori setup internal, untuk kemudian dirubah menjadi aktifitas setup eksternal, (3) merampingkan semua aspek operasi waktu setup. SMED menurut Coimbra (2009) pada akhirnya akan menghasilkan dua manfaat utama yaitu meningkatkan produksi kapasitas dan meningkatkan fleksibilitas peralatan, hal ini memungkinkan pekerjaan diubah kedalam dengan ukuran batch yang lebih kecil, membuat aliran material sehingga dapat menghilangkan waiting time dari satu proses ke proses berikutnya.

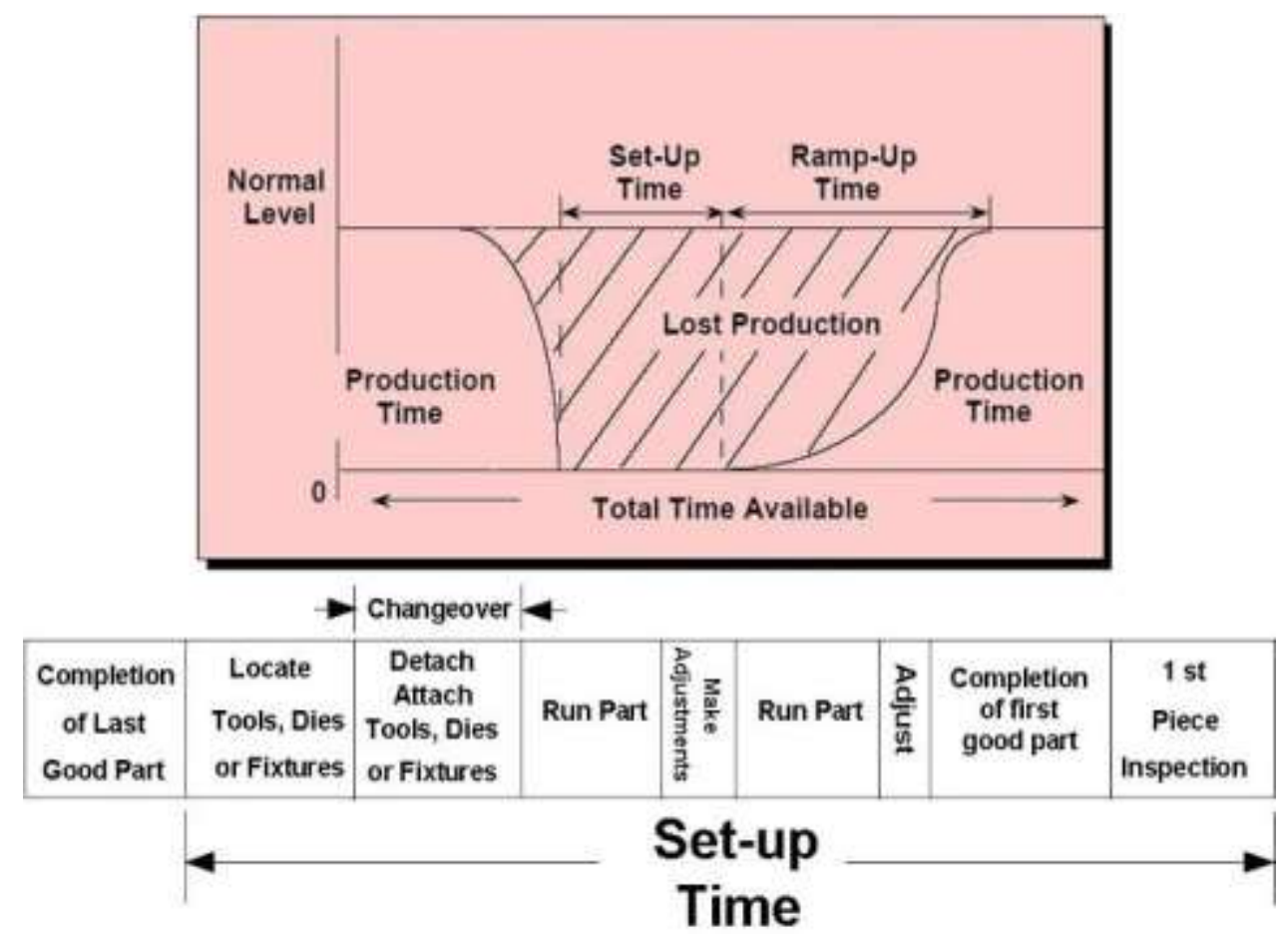

Gambar 1. Kegiatan Yang Termasuk Ke Dalam Waktu Setup

Sumber: Syafiq (2018)

\section{Pengukuran Waktu Kerja}

Menurut Wignjosoebroto (2003) pengertian dari pengukuran waktu kerja adalah suatu pengukuran waktu kerja (time study) suatu aktivitas untuk menentukan waktu yang dibutuhkan oleh seorang operator (yang memiliki skill rata-rata atau terlatih dengan baik) dalam melaksanakan sebuah kegiatan kerja dalam kondisi dan tempo normal. Tujuan pengukuran waktu kerja adalah untuk menentukan waktu rata-rata yang dibutuhkan dalam 
melakukan sebuah pekerjaan oleh operator terlatih untuk melakukan suatu pekerjaan jika harus melakukannya selama 8 jam dalam sehari, pada kondisi kerja yang biasa dan bekerja dalam kecepatan normal. Dimana waktu ini disebut dengan waktu standar. Dengan menerapkan prinsip dan teknik pengaturan tata cara kerja yang optimal dalam system kerja tersebut, maka akan diperoleh alternatif pelaksanaan kerja yang dapat memberikan hasil yang terbaik.

Teknik-teknik pengukuran waktu dapat dikelompokan menjadi dua kelompok besar menurut Wignjosoebroto (2003), yaitu: (1) Pengukuran kerja secara langsung, pengukuran dilakukan secara langsung pada tempat dimana pekerjaan yang diukur dijalankan, dengan menggunakan jam henti (stopwatch time study) dan work sampling, (2) Pengukuran kerja secara tidak langsung, pengukuran dilakukan secara tidak langsung oleh pengamat. Pengamat melakukan pengukuran dengan membagi elemen-elemen kerja yang ada kemudian membaca waktu berdasarkan tabel waktu. Pemulihan pengukuran waktu kerja ini harus disesuaikan dengan kebutuhan dan kondisi yang berjalan, karena masing-masing pengukuran waktu kerja ini memiliki tujuan dan karakteristik yang harus dimengerti. Pemilihan metode yang kurang tepat dapat menyebabkan kehilangan waktu, sehingga diperoleh pengukuran tambahan atau pengukuran ulang dengan metode yang tepat.

\section{METODOLOGI}

Mesin yang menjadi objek penelitian adalah Mesin Manual B070 dan mesin L224 pada Line Seat Departemen Press Shop. Mesin produksi ini membutuhkan waktu lebih lama dibanding mesin produksi lainnya. Dalam proses setup untuk pergantian dies (cetakan) saat peralihan dari part number yang satu ke part number yang lainnya karena elemen proses setting panjang. Sesuai dengan tujuan penelitian untuk melakukan perbaikan waktu dan elemen proses setting per part, agar dapat meningkatkan efektifitas mesin. waktu changeover part (COP) dengan menggunakan SMED. Tahapan yang dilakukan adalah sebagai berikut:

(1) Melakukan analisa lapangan untuk mengidentifikasi dan mencatat semua kegiatan yang dilakukan operator dalam melakukan setup mesin B0770 dan L224, dan dibuatkan flow prosesnya. Pada langkah ini pengukuran waktu kerja tiap aktifitas dicatat secermat mungkin. Pengukuran waktu kerja tiap elemen proses menggunakan 15 kali data pengamatan. Pengukuran waktu tiap elemen proses change over part seat menggunakan jenispengukuran waktu langsung yaitu pengukuran jam henti dengan alat bantu stopwatch. Pengolahan data diawali dengan uji kecukupan data dari waktu elemen proses tiap mesin kemudian dilakukan uji keseragaman data untuk memastikan tidak adanya data ekstrim. Setelah dipastikan data lapangan yang diambil memenuhi uji kecukupan data dan keseragaman data, maka dilakukan waktu siklus tiap elemen proses dengan rumus:

$$
\begin{aligned}
& \mathrm{WS}=\Sigma \mathrm{Xi} / \mathrm{N} \\
& \mathrm{Ket}: \\
& \mathrm{Xi}=\text { Jumlah waktu penyelesaian yang teramati } \\
& \mathrm{N}=\text { Jumlah pengamatan yang dilakukan }
\end{aligned}
$$

(2) Implementasi tahapan SMED. Dengan tahapan (a) memisahkan pengaturan setup internal dan setup eksternal, (b) mengidentifikasi aktifitas apa saja yang termasuk kategori setup internal, untuk kemudian dirubah menjadi aktifitas setup eksternal, (c) merampingkan semua aspek operasi waktu setup.

(3) Dari kondisi (1) dan (2) dilakukan analisa, pada proses apa saja terjadi pemborosan waktu dalam aktifitas setup mesin dan apa akar penyebabnya dengan diagram fishbone untuk kemudian dicari solusi masalahnya. 


\section{HASIL DAN PEMBAHASAN}

Hasil pengamatan sebelum dilakukan implementasi SMED memberikan gambaran proses change over part Seat yang menggunakan mesin B070 dan L224 terlihat pada Gambar 1.



Gambar 1. Flow Process Change Over Part Seat

Sumber: Dept Produksi, PT. SS, 2019

Adapun hasil pengukuran waktu siklus tiap elemen proses pada mesin B070 dan L224 tersajo pada Tabel 2 dan Tabel 3.

Tabel 2. Waktu Pengukuran Tiap Elemen Proses Mesin B070 (detik)

\begin{tabular}{|c|l|c|}
\hline No & \multicolumn{1}{|c|}{$\begin{array}{c}\text { Elemen } \\
\text { Proses }\end{array}$} & Waktu \\
\hline 1. & Pengecekan OC & 26 \\
\hline 2. & Pengambialan Dies (Dies P1 \& P2) & 132 \\
\hline 3. & Persiapan Tool (Kunci) & 28 \\
\hline 4. & Bongkar-Pasang Dies P1 & 250 \\
\hline 5. & Potong Material & 955 \\
\hline 6. & Setting Dies P1 & 38 \\
\hline & TOTAL & $\mathbf{1 4 2 9}$ \\
\hline
\end{tabular}


Tabel 3. Waktu Pengukuran Tiap Elemen Proses Mesin L224 (detik)

\begin{tabular}{|c|l|c|}
\hline No & \multicolumn{1}{|c|}{ Elemen Proses } & Waktu \\
\hline 1. & Bongkar-Pasang Dies P2 & 229 \\
\hline 2. & Setting Dies P2 & 46 \\
\hline 3. & Verifikasi Produk ke QC & 257 \\
\hline \multicolumn{2}{|c|}{ TOTAL } & $\mathbf{5 3 2}$ \\
\hline
\end{tabular}

Dari hasil penelitian yang didapat di Mesin Manual B070 \& L224 di line SEAT Press Shop. Di mesin ini membutuhkan waktu dalam proses setup yang lama untuk pergantian dies (cetakan) saat peralihan dari part number yang satu ke part number yang lainnya dibandingkan dengan mesin lainnya, karena elemen proses setting panjang (ada sembilan elemen proses). Sehingga masalah yang di dapat di Mesin Mekanik Manual B070 \& L224 adalah Waktu pergantian part number atau Change Over Part (COP) panjang. Dan untuk menemukan akar penyebab dari masalah Waktu pergantian part number atau Change Over Part (COP) panjang, menggunakan Diagram Fishbone dengan kategori 4M (Man, Material, Methode dan Mesin). Berikut ini akar penyebab masalah yang didapat bisa dilihat pada Gambar 2.

Analisa fishbone menunjukkan akar masalah penyebab waktu setup lama pada mesin B070 dan L224, diperoleh bahwa pada faktor material bahan yang belum dipotong merupakan akar penyebab masalah, faktor krusial lainnya yang menjadi akar penyebab masalah terdapat pada faktor metode, yaitu tidak tersedianya tempat persiapan dies yang memadai sehingga kerja operator terhambat dan tidak adanya pemisahan aktifitas setup internal dan eksternal. Untuk mengatasi akar penyebab ini, maka solusi yang dikerjakan untuk faktor material bahan adalah dengan menyediakan bahan yang sudah terpotong dan siap pakai oleh operator, kemudian disiapkan juga meja preparation untuk menyiapkan dies yang akan digunakan, sehingga operator tidak harus mengambil dies dari tempat penyimpanan yang jauh.

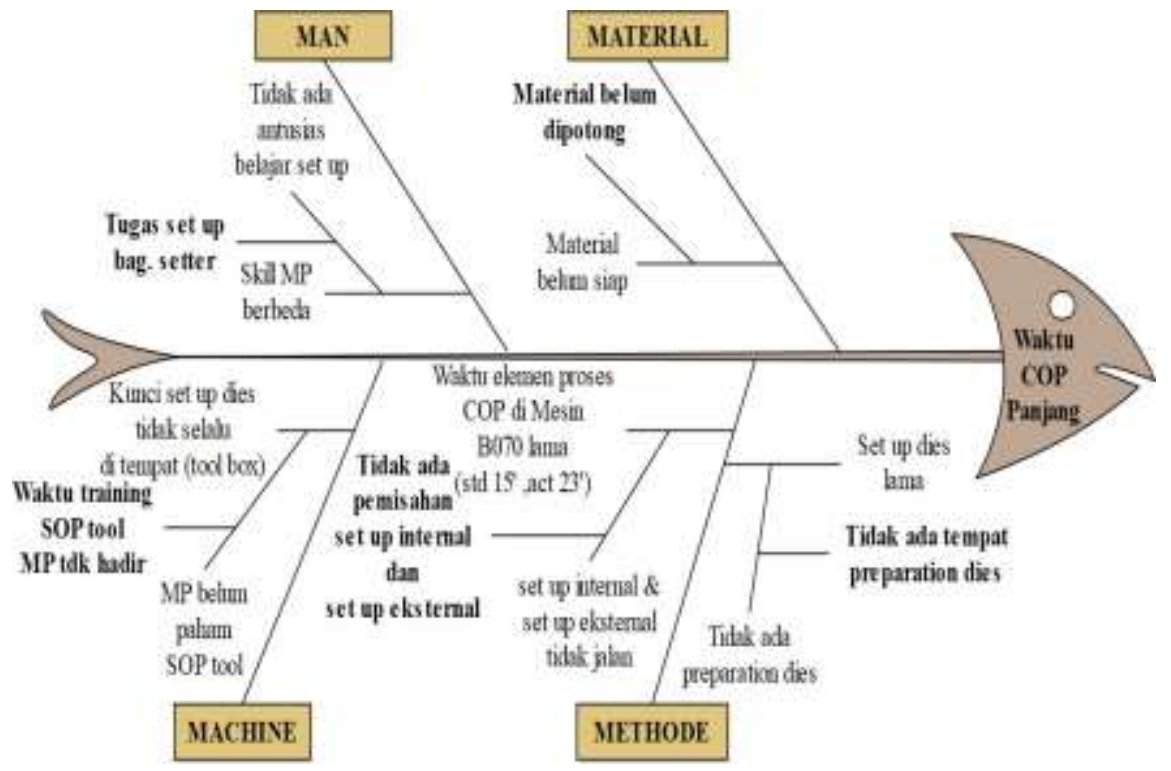

Gambar 2. Fishbone Diagram penyebab Waktu COP Lama. 
Implementasi SMED dilakukan untuk memperbaiki waktu setup ke dua mesin tersebut, adapun langkah-langkah dalam SMED memberikan tahapan perbaikan sebagai berikut:

(a) memisahkan pengaturan setup internal dan setup eksternal

Tabel 4. Hasil Perubahan Waktu Proses COP Di Mesin B070

\begin{tabular}{|c|c|c|c|c|}
\hline No & External Set Up & Time & Internal Set Up & Time \\
\hline 1. & Pengecekan OC (Order Card) & 26 & $\begin{array}{l}\text { Pengambilan dies P-1 } \\
\text { di meja persiapan }\end{array}$ & 46 \\
\hline 2. & Pengambilan dies di rak & 132 & $\begin{array}{l}\text { Bongkar-Pasang Dies } \\
\text { P1 }\end{array}$ & 250 \\
\hline 3. & Persiapan kunci (tools) & 28 & Setting Dies P1 & 38 \\
\hline 4. & Potong material & 955 & - & \\
\hline & TOTAL TIME (detik) & 1141 & & 334* \\
\hline
\end{tabular}

(b) mengidentifikasi aktifitas apa saja yang termasuk kategori setup internal, untuk kemudian dirubah menjadi aktifitas setup eksternal.

Dari hasil (perbaikan) memisah waktu eksternal setup \& internal setup mesin manual B070, berikut flow elemen proses Change Over Part (COP) di mesin B070 dan penjelasanya bisa dilihat pada Gambar 3. Pada saat proses produksi selesai dan mesin berhenti, untuk melakukan peralihan atau pergantian dies (cetakan) saat peralihan dari part number yang satu ke part number berikutnya yang akan di produksi, elemen proses pertama yang dilakukan yaitu sama mengambil dies, tapi dalam pengambilanya hanya di tempat meja persiapan dies yang di sebelah mesin dan hanya dies P-1 (B070) saja yang diambil.

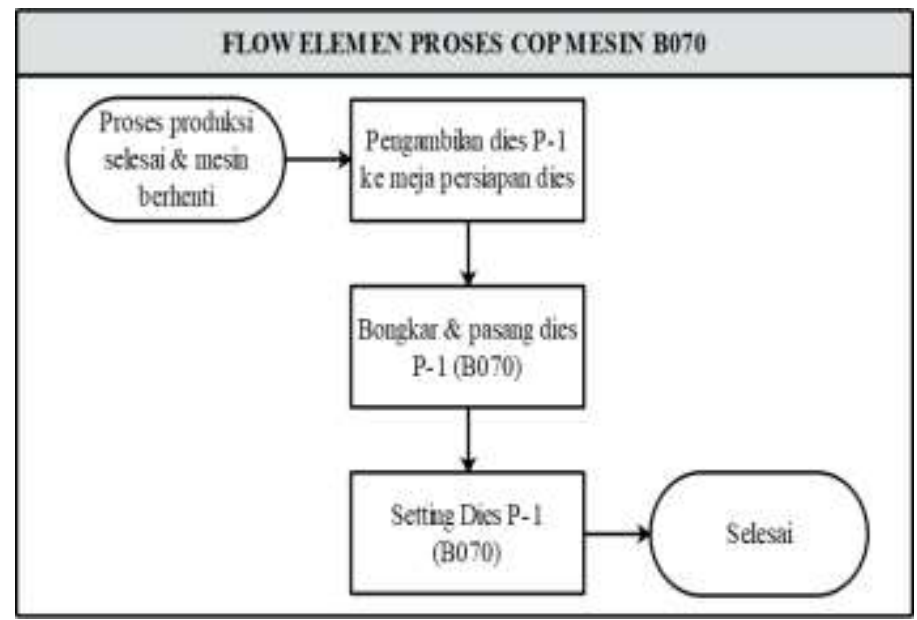

Gambar 3. Flow Elemen Proses COP Mesin B070

(c) merampingkan semua aspek operasi waktu setup.

Setelah mengetahui akar penyebab masalah waktu change over part panjang dan dilakukan perbaikan, ada perubahan waktu dan elemen proses di mesin manual B070. Dan untuk waktu dan elemen proses di mesin L224 tetap sama, karena tidak ada elemen proses yang dilakukan pada waktu eksternal setup. Tabel 5 menunjukkan perubahan waktu dan elemen proses change over part seat. 
Tabel 5. Perubahan Waktu \& Elemen Proses COP Seat

\begin{tabular}{clc}
\hline NO. MESIN & \multicolumn{1}{c}{ ELEMEN PROSES } & WAKTU (Detik) \\
\hline \multirow{3}{*}{ BO70 } & Pengambilan dies P-1 di meja persiapan & 46 \\
\cline { 2 - 3 } & Bongkar-Pasang Dies P1 & 250 \\
\cline { 2 - 3 } & Setting Dies P1 & 38 \\
\hline \multirow{2}{*}{ L224 } & Bongkar-Pasang Dies P2 & 229 \\
\cline { 2 - 3 } & Setting Dies P2 & 46 \\
\cline { 2 - 3 } & Verifikasi Produk ke QC & 257 \\
\hline
\end{tabular}

(*) Waktu COP

Setelah dilakukan perbaikan pemisahan eksternal setup dan internal setup, maka total waktu yang dibutuhkan untuk change over part seat adalah 866 detik. Dari hasil perbaikan ada perubahan dalam elemen proses Change Over Part Seat dari sebelumnya ada sembilan elemen proses dan setelah dilakukan perbaikan ada enam elemen proses. Berikut perubahan Flow Process Change Over Part dan penjelasanya, Untuk flow prosesnya bisa di lihat pada Gambar 4. Penjelasan dari Flow Process Change Over Part adalah pada saat proses produksi selesai dan mesin berhenti, untuk melakukan peralihan atau pergantian dies (cetakan) saat peralihan dari part number yang satu ke part number berikutnya yang akan di produksi, elemen proses pertama yang dilakukan yaitu sama mengambil dies, tapi dalam pengambilanya hanya di tempat meja persiapan dies yang di sebelah mesin. Karena dengan adanya meja persiapan dies tesebut, pengambilan dies bisa dilakukan pada saat setup eksternal. Elemen proses berikutnya bongkar \& pasang dies P-1 dan P-2. Setelah selesai proses tersebut bisa langsung setting dies P-1 \& P-2 tanpa menunggu material yang akan digunakan untuk setting dies, karena bahan sudah siap. Pemotongan bahan dikerjakan pada saat setup eksternal (Mesin masih beroperasi). Dalam penyetinggan tersebut sama pada elemen proses change over part sebelumnya, yaitu sampai menghasilkan komponen yang sesuai standar. Dan selanjutnya melakukan verifikasi komponen tersebut ke Quality Control sampai komponen tersebut OK sesuai standar apperance produk. Kemudian bisa langsung proses produksi. Hasil efisiensi waktu change over part memberikan efek terhadap peningkatan output permenit, dengan waktu COP menjadi $18 \mathrm{menit} / \mathrm{setup}$ dan output permenit produk menjadi $180 \mathrm{pcs} / \mathrm{menit}$. Dengan waktu kerja 3 shift perhari dan selama sebulan asumsi hari kerja efektif 26 hari, maka didapat hasil produksi per bulan mencapai $28080 \mathrm{pcs} / \mathrm{bulan}$. 


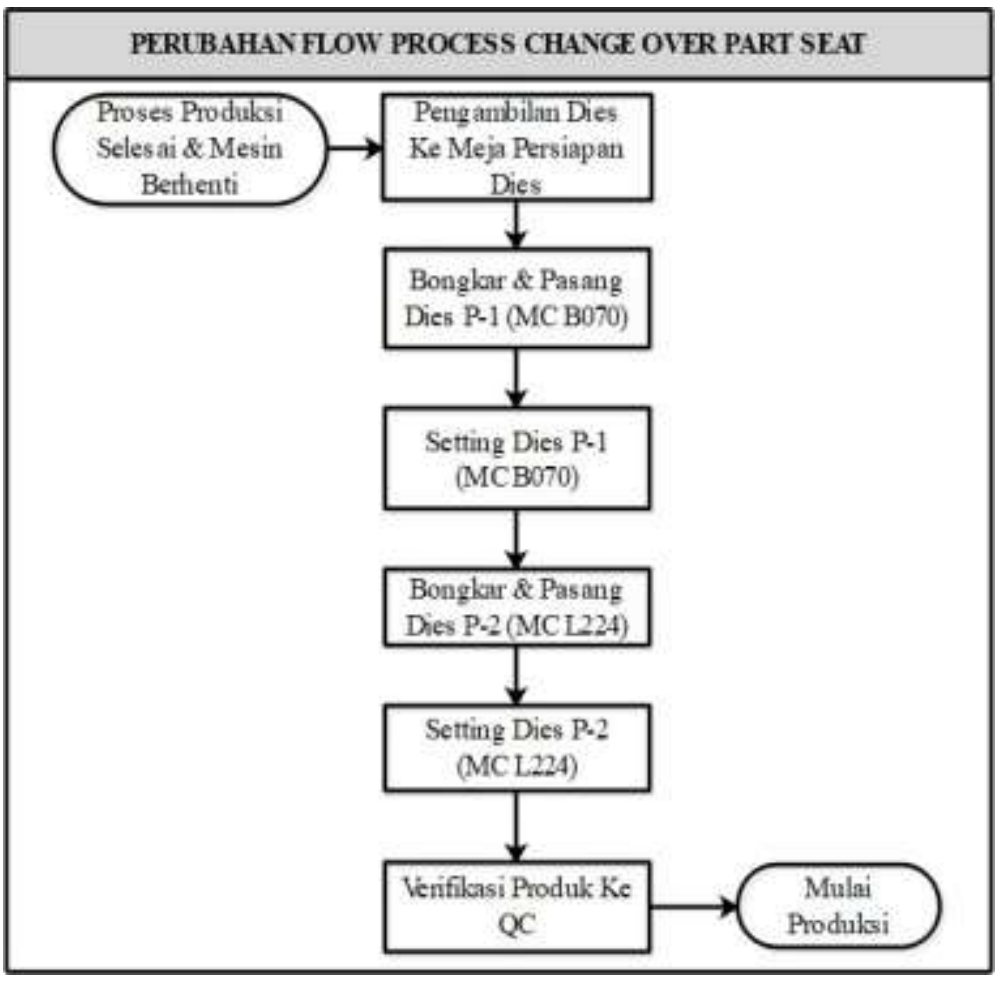

Gambar 4. Perubahan Flow Elemen Proses COP Mesin B070 Setelah Improve

\section{SIMPULAN DAN SARAN}

Dari hasil penelitian di mesin manual B070 dan L224 line seat Departemen Press shop PT. Selamat Sempurna, Tbk masalah di mesin tersebut adalah waktu change over part (COP) panjang ada sembilan elemen proses yaitu Pengecekan Order Card (OC), Pengambilan dies ke rak dies, Persiapan kunci (tools), Bongkar-pasang dies P-1, Bongkar pasang dies P-2, Potong material, Setting Dies P-1, Setting Dies P-2 dan verifikasi produk ke Quality Control (QC). Dengan diagram fishbone akar penyebab masalah waktu change over part (COP) panjang di mesin manual B070 dan L224 dikarenakan tidak adanya pemisahan kegiatan external dan internal setup serta tidak adanya tools untuk persiapan saat setup. Waktu yang di butuhkan untuk change over part sebelum improvement adalah 1961 detik (32.13 menit/ setup). Waktu yang di butuhkan untuk change over part sesudah improvement adalah 866 detik (14.43 menit/ setup). Dan efisiensi waktu rata - rata 1095 detik (18 menit/ setup). Saran perbaikan terhadap pemisahan waktu setup internal dan ekternal ini dapat diimplementasikan untuk mesin-mesin lainnya yang digunakan di line produksi.

\section{DAFTAR PUSTAKA}

Fauzi, M. I. (2018). Pengoptimalan Proses Setup Untuk Mengurangi Waktu Changeover Menggunakan Metode SMED Line Housing F PT. Inti Ganda Perdana. Industrial Engineering Jurnal, Vol. 4 No. 2, pp 45-55.

Hendri, H. (2015). Penurunan Waktu Setup Untuk Peningkatan Efektifitas Pada PT. X. Sinergi : Jurnal Teknik Mercu Buana, Vol. 19 No. 2, pp. 91-100.

Luo, Y., Huang, S \& Cao, S. (2007). Aplication of Improved Fishbone Diagram In The Operation Management. Industrial Engineering Jurnal, Vol. 10 No. 2, pp. 138.

Mufidah, I \& Yekti, Y. N. (2012). Analisis Dan Pengukuran Kerja : Upaya Untuk Meningkatkan Efektifitas \& Efesiensi Kerja. Yogyakarta : Penerbit Deepublish.

Mulyana, A \& Hasibuan, S. (2017). Implementasi Single Minute Exchange of Dies untuk Optimasi Waktu Changeover Model Pada Produksi Panel Telekomunikasi. Sinergi : Jurnal Teknik Mercu Buana, Vol. 21 No. 2, pp. 107-114. 
Murnawan, H. (2016). Perencanaan Produktivitas Kerja Dari Hasil Evaluasi Produktivitas Dengan Metode Fishbone Di Perusahaan PT. X. Heuristic ; Jurnal teknik Industri, Vol. 11 No. 1, pp. 27-46.

Nasution, M. N. (2001). Manajemen Mutu Terpadu (Total Quality Manajemen). Jakarta : Ghalia Indonesia.

Prasetyowati, N. P., Rahman, A. \& Tantrika, C. (2013). Perbaikan Waktu Setup Dengan Pendekatan SMED Untuk Mengurangi Unnecessary Motion Waste (Studi Kasus: PT. Berlina Tbk). Jurnal Rekayasa dan Manajemen Sistem Industri, Vol. 1 No. 1, pp. 1-10.

PT. Selamat Sempurna, Tbk. (2019). Company Profile. Tangerang.

Saputra, R., Arianto, H. \& Irianti, L. (2016). Usulan Meminimasi Waktu Setup dengan Menggunakan Metode Single Minute Exchange Of Die Di Perusahaan

X. Jurnal Online Institut Teknologi Nasional, Vol. 4 No. 2, pp. 206-218.

Sudargo, K. W. (2015). Penurunan Waktu Changeover Dengan Metode SMED Di PT. Schneider Electric Manufacturing Batam. Jurnal Titra, Vol. 3 No. 2, pp. 35-40.

Suhardi, B., \& Satwikaningrum, D. (2015). Perbaikan Waktu Setup Dengan Menggunakan Metode SMED. Industrial Engineering National Journal, Vol. 6 No. 2, pp. 246250.

Syafiq, A. N. (2018). Implementasi Single Minutes Exchange Of Dies Saat Changeover Kabinet Pada Proses Produksi Di Mesin NC PT. Yamaha Indonesia. Jurnal Teknik Industri, Vol. 4 No. 2, pp. 46-54.

Wignjosoebroto, S. (2003). Pengantar Teknik Dan Manajemen Industri. Surabaya : Prima Printing. 